\title{
SEPT9 wt Allele
}

National Cancer Institute

\section{Source}

National Cancer Institute. SEPT9 wt Allele. NCI Thesaurus. Code C97898.

Human SEPT 9 wild-type allele is located in the vicinity of $17 q 25.3$ and is approximately $219 \mathrm{~kb}$ in length. This allele, which encodes septin-9 protein, is involved in the regulation of microfilament formation. Mutation of the gene is associated with hereditary neuralgic amyotrophy. A chromosomal translocation $\mathrm{t}(11 ; 17)(\mathrm{q} 23 ; \mathrm{q} 25)$ of this gene and the MLL gene is associated with acute myeloid leukemia. 